\title{
Early determinants of physical activity in adolescence: prospective birth cohort study
}

Pedro C Hallal, Jonathan C K Wells, Felipe F Reichert, Luciana Anselmi, Cesar G Victora

\begin{abstract}
Objective To examine the effects of early social, anthropometric, and behavioural variables on physical activity in adolescence.

Design Prospective birth cohort study.

Setting Pelotas, southern Brazil.

Participants 4453 adolescents aged 10-12 years participating in the Pelotas 1993 birth cohort study (follow-up rate 87.5\%).

Main outcome measures Sedentary lifestyle ( $<300$ minutes of physical activity per week) and median physical activity score (minutes per week).

Results The prevalence of a sedentary lifestyle at age 10-12 years was $58.2 \%$ (95\% confidence interval $56.7 \%$ to $59.7 \%$ ). Risk factors for a sedentary lifestyle in adolescence were female sex, high family income at birth, high maternal education at birth, and low birth order. Weight gain variables at ages $0-1,1-4$, and 4-11 years and overweight at age 1 or 4 years were not significant predictors of physical activity. Levels of physical activity at age 4 years, based on maternal report, were inversely related to a sedentary lifestyle at age 10-12 years.

Conclusions Physical activity in adolescence does not seem to be programmed by physiological factors in infancy. A positive association between birth order and activity may be due to greater intensity of play in childhood and adolescence. Tracking of physical activity from age 4 to 10-12 years, however, suggests that genetic factors or early habit formation may be important.
\end{abstract}

\section{Introduction}

The benefits of physical activity on physical and mental health throughout life are well established. ${ }^{12}$ Leading health agencies have included physical activity in their public health agendas. ${ }^{3}$ Although most chronic diseases associated with physical inactivity typically occur in middle aged and older adults, it is increasingly understood that their development starts in childhood and adolescence. ${ }^{4}$ This highlights the need for studies of determinants of physical activity in childhood and adolescence, taking into account that physical activity is a complex behaviour, influenced by several linked factors. ${ }^{5}$

Most studies of physical activity among adolescents are cross sectional. For identifying possible early determinants of physical activity behaviour, prospective studies are required. Interest in the idea of "programming" of health status by factors operating in early life is widespread. ${ }^{6-9}$ Most studies have focused on physiological outcomes, such as blood pressure, ${ }^{10}{ }^{11}$ diabetes, ${ }^{12}$ obesity, ${ }^{13}$ and body composition. ${ }^{14}$ Behaviour might also be programmed in early life, as pointed out by Freud. ${ }^{15}$ We examined the effect of early social, anthropometric, and behavioural variables on levels of physical activity in 10-12 year olds.

\section{Methods}

Pelotas (population 320 000) is located in southern Brazil in a relatively developed part of the country. In 1993, mothers of all hospital born children were invited to join a birth cohort study. Home births account for less than $1 \%$ of all deliveries. Mothers were interviewed soon after delivery for personal, socioeconomic, and behavioural variables. Family income was divided into five groups $(\leq 1,1.1-3,3.1-6,6.1-10,>10$ minimum wages per month). Mother's education was defined as the highest degree completed $(0,1-4,5-8, \geq 9$ years). Prepregnancy weight was obtained by self report from the mothers, and the mothers' height was measured at the hospital with portable stadiometers (precision $1 \mathrm{~mm}$ ). The prepregnancy body mass index was then calculated and divided into four categories $(<20,20-24.9$, $25-29.9, \geq 30$ ). Birth order was categorised into 1,2 or 3 , and $\geq 4$. Newborn infants were weighed using scales with a precision of $100 \mathrm{~g}$, and birth weight was categorised into three groups $(<2500,2500-3499, \geq 3500 \mathrm{~g})$. The methods are described in detail elsewhere. ${ }^{16}$

\section{Follow-up visits}

The cohort has been followed on several occasions. In the present analysis we use data from four follow-up visits.

\section{One year and four years}

At follow-up visits at one and four years, all low birthweight $(<2500 \mathrm{~g})$ children $(\mathrm{n}=510)$ and a systematic sample of $20 \%$ of the remainder were sought; 1363 children were seen at one year and 1273 at four years. Analyses were weighted to compensate for the over-sampling of low birthweight children. Weight gains (kg) from birth to 1 year, 1-4 years, and 4-11 years were categorised into quartiles. Overweight at 1 and 4 years was defined as weight for height $\mathrm{Z}$ scores greater than 2 according to the reference standard of the National Center for Health Statistics. ${ }^{17}$

\section{Behavioural substudy at four years}

A randomly selected subsample of 634 children followed up at four years was visited. At this visit the mother completed the child behaviour checklist questionnaire. ${ }^{18}$ We used two variables on the basis of the mother's self report in the present paper: the child's level of physical activity compared with children of the same age (below average, on average, above average) and how well the child performed at sports activities (below average, on average, above average). 
10-12 years

In 2004-5 we sought all cohort members through a school census, as well as a population census in which about 100000 households in the urban area were visited in search of adolescents born in 1993. Detailed data were collected on physical activity, including mode of transportation to and from school, physical education classes, and leisure time activities. We defined a sedentary lifestyle as less than 300 minutes of physical activity per week, in accordance with current guidelines for adolescents. ${ }^{19}$ We did not include physical education classes because these were carried out only two or three times a week, with low intensity of activity. The field work was carried out from July 2004 to March 2005 by interviewers who were unaware of the study's objectives. A random sample of $10 \%$ of the interviews was repeated by a supervisor for quality control. Mothers gave written informed consent, and confidentiality was ensured.

Following descriptive analysis, we compared the prevalence of sedentary lifestyle across subgroups of the independent variables using $\chi^{2}$ tests for heterogeneity and linear trend. Because the variable of minutes per week of physical activity was noticeably skewed, we compared medians using the non-parametric $\mathrm{K}$ sample test on the equality of medians (Stata 8.0). We have reanalysed our dataset with other non-parametric tests for comparing distributions, but the results provided in tables 2-4 were virtually unchanged. We carried out multivariable analyses using Poisson regression (Wald's test). ${ }^{20}$ This approach was used instead of logistic regression because, given the high prevalence of sedentary lifestyle, odds ratios overestimate prevalence ratios. ${ }^{20}$ We repeated the analyses using logistic regression and found virtually no change in the significance of the associations (data not shown).

Variables were included in Poisson regression in accordance with a conceptual framework defined a priori. ${ }^{21}$ This model incorporated all perinatal characteristics in the first hierarchical level of determination, variables collected at one year and four years in the second level, and variables collected in the behavioural substudy in the third level. We adjusted variables for other variables in the same and higher levels of determination that presented an association of $\mathrm{P}<0.20$ with the outcome. Owing to the different sampling fractions of low birthweight and normal birthweight children, we weighted analyses of second and third level variables.

\section{Results}

In 1993, 5265 live births occurred in Pelotas, southern Brazil; 16 mothers refused to participate in a birth cohort study, resulting in a cohort of 5249 children. At follow-up in 2004-5, 4453 adolescents were interviewed. Taking into account 141 participants who had died, this corresponded to $87.5 \%$ of the cohort. Table 1 presents selected baseline variables for adolescents located at age 10-12 years. No significant differences were observed for sex and birth weight. Low socioeconomic status, low maternal education, and high maternal body mass index were associated with higher follow-up rates, but at least $79.9 \%$ of children in each subgroup were traced.

The prevalence of a sedentary lifestyle at 10-12 years was $58.2 \%$ (95\% confidence interval $56.7 \%$ to $59.7 \%$ ). The median physical activity score was 235 minutes per week (mean 415 (SD 765 ) minutes per week), showing high skewness. All but $0.8 \%$ of the adolescents attended school, and these had an average of 2.2 physical education classes per week, each entailing about 30 minutes of low to moderate intensity. If physical education
Table 1 Comparison between those followed up at 10-12 years and original cohort in terms of sociodemographic and anthropometric variables

\begin{tabular}{lccc} 
Variable & $\begin{array}{c}\text { No in original } \\
\text { cohort }(\mathrm{n}=5247)^{*}\end{array}$ & $\begin{array}{c}\text { \% located } \\
\text { Sex: }\end{array}$ & $\begin{array}{c}\mathrm{P} \text { value }\left(\boldsymbol{\chi}^{2}\right. \\
\text { test })\end{array}$ \\
\hline Boys & 2580 & 86.9 & \\
\hline Girls & 2667 & 88.1 & 0.18 \\
\hline
\end{tabular}

Family income (No of minimum

wages per month):

\begin{tabular}{|c|c|c|c|}
\hline$\leq 1$ & 967 & 88.3 & \multirow{5}{*}{$<0.001$} \\
\hline $1.1-3.0$ & 2260 & 88.7 & \\
\hline $3.1-6.0$ & 1204 & 88.9 & \\
\hline $6.1-10.0$ & 433 & 79.9 & \\
\hline$>10.0$ & 385 & 82.6 & \\
\hline \multicolumn{4}{|c|}{ Maternal education at birth (years): } \\
\hline 0 & 134 & 82.1 & \multirow{4}{*}{$<0.001$} \\
\hline $1-4$ & 1338 & 88.7 & \\
\hline $5-8$ & 2424 & 89.9 & \\
\hline$\geq 9$ & 1350 & 82.5 & \\
\hline \multicolumn{4}{|c|}{ Birth weight $(\mathrm{g})$ : } \\
\hline$<2500$ & 510 & 89.8 & \multirow{3}{*}{0.16} \\
\hline $2500-3499$ & 3361 & 86.9 & \\
\hline$\geq 3500$ & 1361 & 87.9 & \\
\hline \multicolumn{4}{|c|}{ Prepregnancy body mass index: } \\
\hline$<20.0$ & 1147 & 87.6 & \multirow{5}{*}{0.004} \\
\hline $20.0-24.9$ & 2811 & 86.6 & \\
\hline $25.0-29.9$ & 894 & 90.3 & \\
\hline$\geq 30$ & 245 & 92.2 & \\
\hline Overall & 5249 & 87.5 & \\
\hline
\end{tabular}

${ }^{*}$ Numbers vary owing to missing values.

†Includes 141 deaths.

classes were included in the activity score, the prevalence of sedentary lifestyles would be reduced to $48.4 \%$ ( $46.9 \%$ to $49.9 \%$ ).

Table 2 presents the crude prevalence of sedentary lifestyle and median physical activity levels (minutes per week) according to perinatal variables. Male sex, low family income, low maternal education, and high birth order were inversely associated with a sedentary lifestyle at 10-12 years. No associations were found for birth weight or prepregnancy body mass index.

Table 3 presents physical activity levels according to variables collected at the follow-up visits at one and four years. No significant associations were found with the variables indicating weight gain or overweight in childhood. Table 4 shows tracking of physical activity from age 4 to 10-12 years. Children classified by their mothers as average or above average (compared with below average) for physical activity at 4 years were more likely to be active at 10-12 years. No significant effect of sports performance at four years was observed.

The effects of sex, maternal education, and birth order did not change after adjustment (table 5). Although the confidence intervals for all categories of maternal education included unity, there was a logical ordering of the prevalence ratios, and the test for linear trend was significant. Family income was not included in the regression model owing to its high collinearity with maternal education, and because maternal education explained a higher proportion of the variance of physical activity. For birth order, the $\mathrm{P}$ value reflects a test for heterogeneity between the three categories, and the main difference is between categories 2 or 3 and $\geq 4$; both of these have confidence intervals that include unity, but the overall effect of the variable is still significant. Indicators of weight gain and overweight collected at one and four years remained unrelated to sedentary lifestyles, even after adjustment for perinatal variables. Maternal classification of physical activity at 4 years was still associated with sedentary lifestyle at 10-12 years in the adjusted model. 
Research

Table 2 Levels of physical activity in 10-12 year olds according to perinatal variables

\begin{tabular}{|c|c|c|c|c|c|}
\hline Variable & No of participants & $\%$ with sedentary lifestyle & $P$ value & $\begin{array}{l}\text { Median physical activity } \\
\text { score (min/week) }\end{array}$ & $P$ value \\
\hline \multicolumn{6}{|l|}{ Sex: } \\
\hline Boys & 2167 & 49.0 & \multirow{2}{*}{$<0.001^{*}$} & 300 & \multirow{2}{*}{$<0.001$} \\
\hline Girls & 2283 & 67.0 & & 185 & \\
\hline \multicolumn{6}{|c|}{ Birth weight $(\mathrm{g})$ : } \\
\hline$<2500$ & 398 & 61.9 & \multirow{3}{*}{$0.23 \ddagger$} & 210 & \multirow{3}{*}{$0.05 \dagger$} \\
\hline $2500-3499$ & 2866 & 58.1 & & 235 & \\
\hline$\geq 3500$ & 1180 & 57.5 & & 240 & \\
\hline \multicolumn{6}{|c|}{$\begin{array}{l}\text { Family income (No of minimum wages } \\
\text { per month): }\end{array}$} \\
\hline$\leq 1$ & 815 & 54.6 & \multirow{5}{*}{$0.001 \ddagger$} & 260 & \multirow{5}{*}{$0.03 \dagger$} \\
\hline $1.1-3.0$ & 1931 & 57.6 & & 240 & \\
\hline $3.1-6.0$ & 1051 & 60.1 & & 230 & \\
\hline $6.1-10.0$ & 339 & 59.3 & & 230 & \\
\hline$>10.0$ & 315 & 63.9 & & 190 & \\
\hline \multicolumn{6}{|c|}{ Maternal education at birth (years): } \\
\hline 0 & 105 & 53.5 & \multirow{4}{*}{$0.001 \ddagger$} & 270 & \multirow{4}{*}{$0.006 \dagger$} \\
\hline $1-4$ & 1133 & 57.4 & & 240 & \\
\hline $5-8$ & 2124 & 56.2 & & 250 & \\
\hline$\geq 9$ & 1086 & 63.2 & & 200 & \\
\hline \multicolumn{6}{|c|}{ Prepregnancy body mass index: } \\
\hline$<20.0$ & 975 & 58.1 & \multirow{4}{*}{$0.44 \ddagger$} & 240 & \multirow{4}{*}{$0.83 \dagger$} \\
\hline $20.0-24.9$ & 2364 & 57.8 & & 240 & \\
\hline $25.0-29.9$ & 780 & 58.6 & & 230 & \\
\hline$\geq 30$ & 220 & 61.8 & & 210 & \\
\hline \multicolumn{6}{|l|}{ Birth order: } \\
\hline 1 & 1558 & 58.3 & \multirow{3}{*}{$0.002^{*}$} & 230 & \multirow{3}{*}{$0.002 \dagger$} \\
\hline 2 or 3 & 2040 & 60.3 & & 223 & \\
\hline$\geq 4$ & 853 & 52.9 & & 270 & \\
\hline
\end{tabular}

${ }^{*} \chi^{2}$ test for heterogeneity.

$\dagger$ Non-parametric K sample test on equality of medians.

$\mp \chi^{2}$ test for trend.

\section{Discussion}

Social and behavioural variables are more important than early biological characteristics in determining physical activity in ado- lescence. Interest in the early origins of chronic diseases is growing. Several variations of the early origins of disease hypothesis ${ }^{6-9}$ concur that diseases in adolescents and adults are partially pro-

Table 3 Levels of physical activity in 10-12 year olds according to variables collected at follow-up visits at age 1 year and 4 years

\begin{tabular}{|c|c|c|c|c|c|c|}
\hline Variable & Mean weight gain $(\mathbf{k g})$ & No & $\begin{array}{l}\% \text { with sedentary } \\
\text { lifestyle }\end{array}$ & $P$ value & $\begin{array}{l}\text { Median physical activity score } \\
\text { (min/week) }\end{array}$ & $P$ value \\
\hline \multicolumn{7}{|l|}{ 0-1 year: } \\
\hline 1st quarter & 5.3 & 303 & 61.0 & \multirow{4}{*}{$0.09^{*}$} & 223 & \multirow{4}{*}{$0.80 \dagger$} \\
\hline 2nd quarter & 6.3 & 303 & 61.3 & & 235 & \\
\hline 3rd quarter & 7.0 & 301 & 58.5 & & 230 & \\
\hline 4th quarter & 8.2 & 302 & 53.7 & & 255 & \\
\hline \multicolumn{7}{|c|}{ 0verweightł at 1 year: } \\
\hline No & - & 1142 & 58.7 & \multirow{2}{*}{$0.51 \S$} & 230 & \multirow{2}{*}{$0.79 \dagger$} \\
\hline Yes & - & 66 & 53.1 & & 263 & \\
\hline \multicolumn{7}{|l|}{ 1-4 years: } \\
\hline 1st quarter & 5.8 & 302 & 58.0 & \multirow{4}{*}{$0.52^{*}$} & 240 & \multirow{4}{*}{$0.96 \dagger$} \\
\hline 2nd quarter & 7.4 & 282 & 57.1 & & 220 & \\
\hline 3rd quarter & 8.1 & 291 & 58.9 & & 230 & \\
\hline 4th quarter & 11.8 & 289 & 58.9 & & 240 & \\
\hline \multicolumn{7}{|c|}{ Overweight + at 4 years: } \\
\hline No & - & 1054 & 57.8 & \multirow{2}{*}{$0.10 \ddagger$} & 240 & \multirow{2}{*}{$0.37 \dagger$} \\
\hline Yes & - & 105 & 63.1 & & 210 & \\
\hline \multicolumn{7}{|l|}{ 4-11 years: } \\
\hline 1st quarter & 12.8 & 290 & 61.2 & \multirow{4}{*}{$0.58 \S$} & 230 & \multirow{4}{*}{$0.40 \dagger$} \\
\hline 2nd quarter & 17.1 & 290 & 54.7 & & 250 & \\
\hline 3rd quarter & 21.8 & 290 & 55.8 & & 230 & \\
\hline 4th quarter & 32.0 & 289 & 61.4 & & 233 & \\
\hline
\end{tabular}

${ }^{*} \chi^{2}$ test for heterogeneity.

†Non-parametric K sample test on equality of medians.

łWeight for height $Z$ scores $>2$.

$\S \chi^{2}$ test for trend. 


\begin{tabular}{|c|c|c|c|c|c|}
\hline $\begin{array}{l}\text { Variable on basis of mother's report compared with other } \\
\text { children }\end{array}$ & No & $\%$ sedentary lifestyle & P value* & $\begin{array}{l}\text { Median physical activity score } \\
\text { (min/week) }\end{array}$ & $P$ value $\dagger$ \\
\hline \multicolumn{6}{|l|}{ Child's physical activity at 4 years: } \\
\hline Below average & 128 & 67.7 & \multirow{3}{*}{0.009} & 178 & \multirow{3}{*}{0.001} \\
\hline Average & 349 & 53.2 & & 270 & \\
\hline Above average & 56 & 53.8 & & 280 & \\
\hline \multicolumn{6}{|l|}{ Child's sports performance at 4 years: } \\
\hline Below average & 100 & 63.0 & \multirow{3}{*}{0.67} & 200 & \multirow{3}{*}{0.84} \\
\hline Average & 261 & 57.9 & & 240 & \\
\hline Above average & 170 & 55.7 & & 230 & \\
\hline
\end{tabular}

${ }^{*} \chi^{2}$ test for heterogeneity.

$\dagger$ Non-parametric K sample test on equality of medians.

grammed in early life. Most studies have focused on physiological outcomes, such as blood pressure, diabetes, and body composition. ${ }^{4}{ }^{610-14}$ The hypothesis that behaviour might also be programmed during early critical windows has received less attention in the recent literature. Most studies on early determinants of physical activity have focused only on tracking of activity levels from infancy to childhood, ${ }^{22}{ }^{23}$ childhood to adolescence, ${ }^{24-26}$ and then on to adulthood. ${ }^{27-29}$ Identification of other possible early determinants is particularly important because a sedentary lifestyle is associated with overweight, a current global epidemic, ${ }^{30-32}$ and with several chronic diseases. ${ }^{1}$ In Pelotas, southern Brazil, for example, $49 \%$ of all people aged 20 years or more have a body mass index $>25$, and about $40 \%$ fail to meet current recommendations for physical activity. ${ }^{3.3}$

We assessed the role of early life factors on physical activity at age 10-12 years within a prospective birth cohort study. Some methodological issues should be taken into account. Because the samples included in each follow-up visit were of different sizes, the power to detect differences was greater for perinatal variables than it was for exposures during childhood. The overall prevalence of the outcome was $58 \%$. Assuming that among unexposed children this frequency would be $50 \%$, we had $90 \%$ power for detecting a prevalence ratio of 1:12 in the whole sample, 1:23 in the follow-up visits at one and four years, and 1:33 in the behavioural substudy. Because we failed to find significant associations for some variables, even in the full dataset, and detected some significant associations in the smallest sample (behavioural substudy), lack of statistical power is unlikely to be responsible for our negative results for perinatal variables and data on variables collected at the one and four year visits.

The overall follow-up rate $(87.5 \%)$ is high for studies in a low to middle income country where participants have to be actively sought. ${ }^{34}$ Although statistically significant, the differences in nonresponse rates according to socioeconomic indicators are unlikely to have affected the present results. The follow-up rates for prepregnancy body mass index ranged from $87 \%$ to $92 \%$ in the different categories; this is unlikely to have caused bias because this variable was not associated with the outcome in the adjusted analyses. The prospective nature of the information on early exposures rules out the possibility of recall bias.

Five variables were identified as being predictors of adolescent physical activity: sex, family income, maternal education, birth order, and reported physical activity at 4 years. The higher level of physical activity among boys concurs with the literature. ${ }^{35}{ }^{36}$ The effect of socioeconomic level on physical activity varies according to the level of development of the population. In high income countries, where manual occupations and walking or cycling to work are less common, overall activity levels are higher among people of a higher socioeconomic group particularly due to leisure time activities. ${ }^{37}{ }^{88}$ In previous studies among adults living in Pelotas, we showed that although upper social class is associated with leisure time physical activity, ${ }^{39}$ low social class is associated with non-leisure time physical activities (commuting, occupation, and housework), leading to an overall higher prevalence of sedentary lifestyles among wealthier people. ${ }^{33}$ In the present study, active transportation (walking or cycling) to and from school was much more common among poor adolescents, whereas the opposite was observed for leisure time activities (data not shown), also leading to an overall higher prevalence of sedentary lifestyles among wealthier people. This is in accordance with the results reported for adults.

To our knowledge the effect of birth order on physical activity has not been previously reported in adolescents. This finding persisted after statistical control for several socioeconomic variables but is difficult to interpret as we do not have information on number of siblings. Birth order has previously been associated with umbilical cord blood concentrations of hormones, ${ }^{40}$ which have in turn been linked to infant behaviour. ${ }^{41}$ Consistent with such evidence for a physiological mechanism linking birth order and activity level, several studies have reported a positive association between these variables in young children..$^{42}$ In our study of adolescents, however, the association between physical activity and birth order was inverse. An alternative explanation, comprising a behavioural mechanism, is that birth order has acted as a proxy for number of siblings. The presence of siblings may provide greater opportunity for games and other physical activities. The theory of family aggregation in physical activity ${ }^{45}$ states that active families protect against sedentary lifestyles, but our results could suggest that a higher number of siblings, irrespective of their activity level, promotes active lifestyles in the long run. Brazil, as with many other middle income countries, is undergoing a noticeable drop in fertility levels ${ }^{46}$; smaller families may thus be contributing to lower levels of physical activity. Further studies are required to examine these competing hypotheses in more detail.

Tracking of physical activity from 4 to 10-12 years was significant, despite using a simple variable based on maternal report to determine activity level in childhood. Previous studies have tracked physical activity and fitness from childhood to adolescence, and most found moderate to high positive correlations. ${ }^{24}{ }^{26}$ Such tracking may reflect genetic tendencies or the early establishment of habitual patterns of activity. Whether the promotion of active lifestyles early in childhood is justified, as has been proposed for adolescence to adulthood, ${ }^{29}{ }^{47} 48$ requires further evidence from prospective studies.

Our negative findings are also of importance. Growth acceleration has been linked with subsequent obesity, ${ }^{13}$ diabetes, ${ }^{12}$ hypertension, ${ }^{10}{ }^{11}$ and cardiovascular disease.$^{9}$ Because physical inactivity is associated with these conditions, ${ }^{12}$ a possible pathway could involve lower levels of activity in children who 
Research

Table 5 Prevalence ratios (95\% confidence intervals) for sedentary lifestyle in 10-12 year olds according to independent variables: crude and adjusted analyses

\begin{tabular}{|c|c|c|c|c|}
\hline Variable & $\begin{array}{l}\text { Crude analysis: } \\
\text { prevalence ratio } \\
(95 \% \mathrm{Cl})\end{array}$ & $P$ value & $\begin{array}{c}\text { Adjusted } \\
\text { analysis: } \\
\text { prevalence ratio } \\
(95 \% \mathrm{CI})\end{array}$ & $P$ value \\
\hline \multicolumn{5}{|c|}{ Level 1: variables collected at perinatal visit $(n=5249)$} \\
\hline \multicolumn{5}{|l|}{ Sex: } \\
\hline Boys & 1.00 & \multirow[b]{2}{*}{$<0.001^{*}$} & 1.00 & \multirow[b]{2}{*}{$<0.001^{\star}$} \\
\hline Girls & $\begin{array}{c}1.37 \\
(1.30 \text { to } 1.44)\end{array}$ & & $\begin{array}{c}1.37 \\
(1.30 \text { to } 1.44)\end{array}$ & \\
\hline \multicolumn{5}{|c|}{ Birth weight $(\mathrm{g})$ : } \\
\hline$<2500$ & $\begin{array}{c}1.08 \\
(0.09 \text { to } 1.18)\end{array}$ & \multirow{3}{*}{$0.23 \dagger$} & $\begin{array}{c}1.03 \\
(0.94 \text { to } 1.14)\end{array}$ & \multirow{3}{*}{$0.81 \dagger$} \\
\hline $2500-3499$ & $\begin{array}{c}1.01 \\
(0.95 \text { to } 1.07) \\
\end{array}$ & & $\begin{array}{c}0.98 \\
\text { (0.93 to } 1.04) \\
\end{array}$ & \\
\hline$\geq 3500$ & 1.00 & & 1.00 & \\
\hline \multicolumn{5}{|c|}{$\begin{array}{l}\text { Maternal education at birth } \\
\text { (years): }\end{array}$} \\
\hline 0 & 1.00 & \multirow{4}{*}{$0.004 \dagger$} & 1.00 & \multirow{4}{*}{0.006} \\
\hline $1-4$ & $\begin{array}{c}1.07 \\
\text { (0.89 to } 1.30)\end{array}$ & & $\begin{array}{c}1.08 \\
(0.89 \text { to } 1.30)\end{array}$ & \\
\hline $5-8$ & $\begin{array}{c}1.05 \\
\text { (0.87 to } 1.27)\end{array}$ & & $\begin{array}{c}1.06 \\
\text { (0.88 to } 1.27) \\
\end{array}$ & \\
\hline$\geq 9$ & $\begin{array}{c}1.18 \\
\text { (0.98 to } 1.43)\end{array}$ & & $\begin{array}{c}1.18 \\
\text { (0.98 to } 1.42)\end{array}$ & \\
\hline \multicolumn{5}{|c|}{ Prepregnancy body mass index: } \\
\hline$<20.0$ & 1.00 & \multirow{4}{*}{$0.44 \dagger$} & 1.00 & \multirow{4}{*}{$0.45 \dagger$} \\
\hline $20.0-24.9$ & $\begin{array}{c}0.99 \\
\text { (0.93 to 1.06) }\end{array}$ & & $\begin{array}{c}0.99 \\
\text { (0.93 to } 1.05) \\
\end{array}$ & \\
\hline $25.0-29.9$ & $\begin{array}{c}1.01 \\
\text { (0.93 to } 1.09)\end{array}$ & & $\begin{array}{c}1.00 \\
\text { (0.92 to } 1.08)\end{array}$ & \\
\hline$\geq 30$ & $\begin{array}{c}1.06 \\
(0.94 \text { to } 1.20)\end{array}$ & & $\begin{array}{c}1.07 \\
\text { (0.96 to } 1.21)\end{array}$ & \\
\hline \multicolumn{5}{|l|}{ Birth order: } \\
\hline 1 & 1.00 & \multirow{3}{*}{$0.003^{*}$} & 1.00 & \multirow{3}{*}{$0.01^{*}$} \\
\hline 2 or 3 & $\begin{array}{c}1.03 \\
(0.98 \text { to } 1.09)\end{array}$ & & $\begin{array}{c}1.03 \\
(0.98 \text { to } 1.09)\end{array}$ & \\
\hline$\geq 4$ & $\begin{array}{c}0.91 \\
(0.84 \text { to } 0.98) \\
\end{array}$ & & $\begin{array}{c}0.92 \\
(0.85 \text { to } 1.00) \\
\end{array}$ & \\
\hline \multicolumn{5}{|c|}{ Level 2: variables collected at one year $(n=1363)$ and four year $(n=1273)$ visits } \\
\hline \multicolumn{5}{|c|}{ Weight gain 0-1 year: } \\
\hline 1st quarter & $\begin{array}{c}1.14 \\
(0.99 \text { to } 1.31)\end{array}$ & \multirow{4}{*}{$0.06 \dagger$} & $\begin{array}{c}1.10 \\
(0.93 \text { to } 1.31)\end{array}$ & \multirow{4}{*}{$0.23 \dagger$} \\
\hline 2nd quarter & $\begin{array}{c}1.14 \\
\text { (0.99 to } 1.32)\end{array}$ & & $\begin{array}{c}1.19 \\
(1.01 \text { to } 1.41)\end{array}$ & \\
\hline 3rd quarter & $\begin{array}{c}1.09 \\
(0.94 \text { to } 1.26) \\
\end{array}$ & & $\begin{array}{c}1.14 \\
(0.97 \text { to } 1.34) \\
\end{array}$ & \\
\hline 4th quarter & 1.00 & & 1.00 & \\
\hline \multicolumn{5}{|c|}{ Overweight $\ddagger$ at 1 year: } \\
\hline No & 1.00 & \multirow[b]{2}{*}{$0.41^{*}$} & 1.00 & \multirow[b]{2}{*}{$0.44^{*}$} \\
\hline Yes & $\begin{array}{c}0.90 \\
\text { (0.71 to } 1.14) \\
\end{array}$ & & $\begin{array}{c}0.90 \\
\text { (0.68 to 1.18) }\end{array}$ & \\
\hline \multicolumn{5}{|c|}{ Weight gain 1-4 years: } \\
\hline 1st quarter & $\begin{array}{c}0.98 \\
\text { (0.86 to } 1.13)\end{array}$ & \multirow{4}{*}{$0.73 \dagger$} & $\begin{array}{c}1.00 \\
\text { (0.82 to } 1.22)\end{array}$ & \multirow{4}{*}{$0.89 \dagger$} \\
\hline 2nd quarter & $\begin{array}{c}0.97 \\
\text { (0.84 to } 1.11) \\
\end{array}$ & & $\begin{array}{c}1.04 \\
\text { (0.86 to } 1.26) \\
\end{array}$ & \\
\hline 3rd quarter & $\begin{array}{c}1.00 \\
(0.87 \text { to } 1.15)\end{array}$ & & $\begin{array}{c}1.05 \\
(0.88 \text { to } 1.25)\end{array}$ & \\
\hline 4th quarter & 1.00 & & 1.00 & \\
\hline \multicolumn{5}{|c|}{ Overweight§ at 4 years: } \\
\hline No & 1.00 & & 1.00 & \\
\hline Yes & $\begin{array}{c}1.09 \\
(0.93 \text { to } 1.28)\end{array}$ & $0.27^{\star}$ & $\begin{array}{c}1.12 \\
\text { (0.96 to } 1.32)\end{array}$ & $0.16^{*}$ \\
\hline
\end{tabular}

Weight gain 4-11 years:

grow rapidly and become overweight. Our data do not, however, support such a hypothesis, suggesting that the association between early growth and chronic diseases may involve other pathways.

$\begin{array}{cccc}\text { Variable } & \begin{array}{c}\text { Crude analysis: } \\ \text { prevalence ratio } \\ (95 \% \mathrm{Cl})\end{array} & \text { P value } & \begin{array}{c}\text { Adjusted } \\ \text { analysis: } \\ \text { prevalence ratio } \\ (95 \% \mathrm{Cl})\end{array}\end{array} \quad$ P value

Level 3: variables collected in behavioural substudy at four years $(n=634)$

Mother's report on child's

physical activity at four years

compared with other children:

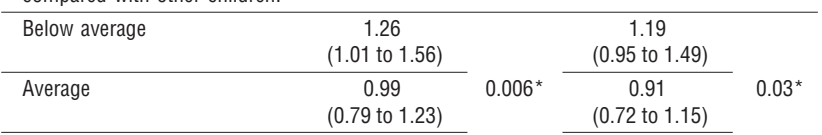

Above average 1.00 1.00

Mother's report on child's sports

performance at four years

compared with other children:

\begin{tabular}{|c|c|c|c|c|}
\hline Below average & $\begin{array}{c}1.13 \\
(0.87 \text { to } 1.46)\end{array}$ & \multirow{3}{*}{$0.65^{\star}$} & $\begin{array}{c}0.98 \\
(0.72 \text { to } 1.32)\end{array}$ & \multirow{3}{*}{$0.88^{*}$} \\
\hline Average & $\begin{array}{c}1.04 \\
(0.87 \text { to } 1.25)\end{array}$ & & $\begin{array}{c}0.99 \\
(0.81 \text { to } 1.22)\end{array}$ & \\
\hline Above average & 1.00 & & 1.00 & \\
\hline
\end{tabular}

*Wald test for heterogeneity.

tWald test for trend.

§Weight for height Z scores $>2$.

In summary, we identified several childhood factors associated with physical activity in adolescence. Data from other birth cohort studies should be analysed to confirm or reject our findings. If our results are confirmed, this has benefits for public health. Intrauterine and early life deprivation may increase the risk of chronic disease but do not restrict physical activity; promotion of active lifestyles may at least in part compensate for the higher future risk faced by such children.

Contributors: $\mathrm{PCH}$ had the original idea for these analyses, coordinated the 2004-5 fieldwork, carried out the literature review, and led the analysis and writing; he is guarantor. JCKW contributed in planning the research project and revising the manuscript. FFR contributed to the fieldwork, analysis, and

\section{What is already known on this topic}

Interest is currently widespread in the idea of programming of health status by factors operating in early life

Most studies have focused on physiological outcomes, such as blood pressure, diabetes, obesity, and body composition

Behaviours might also be programmed during early critical windows

\section{What this study adds}

Physical activity behaviour in adolescence is partially programmed by social and behavioural factors operating in early life

High birth order and level of physical activity at age 4 years were significant predictors of physical activity in adolescence

The pathway through which early growth acceleration increases the risk of chronic diseases in adulthood does not seem to be mediated by low activity levels 


\section{Research}

writing. LA coordinated the behavioural substudy in 1997-8 and commented on the manuscript. CGV coordinated the Pelotas 1993 birth cohort study, revised the research protocol, and contributed to the analysis and writing.

Funding: The Wellcome Trust initiative "major awards for Latin America on health consequences of population change." Earlier phases of the 1993 cohort study were funded by the European Union, the National Program for Centers of Excellence (Brazil), the National Research Council (Brazil), and the Ministry of Health (Brazil).

Competing interests: None declared.

Ethical approval: Federal University of Pelotas Medical School ethics committee, affiliated with the Brazilian Federal Medical Council.

1 Bauman AE. Updating the evidence that physical activity is good for health: an epidemiological review 2000-2003.J Sci Med Sport 2004;7:S6-19.

2 US Department of Health and Human Services. Physical activity and health: a report from the surgeon general. Atlanta: National Center for Chronic Disease Prevention and Health Promotion, 1996.

3 World Health Organization. Global strategy on diet, physical activity and health. Geneva: WHO, 2004.

4 Parsons TJ, Power C, Logan S, Summerbell CD. Childhood predictors of adult obesity: a systematic review. Int J Obes Relat Metab Disord 1999;23:S1-107.

5 Trost SG, Owen N, Bauman AE, Sallis JF, Brown W. Correlates of adults' participation in physical activity: review and update. Med Sci Sports Exerc 2002;34:1996-2001.

6 Barker DJ, Gluckman PD, Godfrey KM, Harding JE, Owens JA, Robinson JS. Feta nutrition and cardiovascular disease in adult life. Lancet 1993;341:938-41.

7 Hales CN, Barker DJ. The thrifty phenotype hypothesis. Br Med Bull 2001;60:5-20.

8 Lucas A. Programming by early nutrition in man. Ciba Found Symp 1991;156:3850; discussion 50-5.

9 Singhal A, Lucas A. Early origins of cardiovascular disease: is there a unifying hypothesis? Lancet 2004;363:1642-5.

10 Forrester T. Historic and early life origins of hypertension in Africans. J Nutr 2004:134:211-6.

11 Horta BL, Barros FC, Victora CG, Cole TJ. Early and late growth and blood pressure in adolescence. J Epidemiol Community Health 2003;57:226-30.

12 Ong KK, Dunger DB. Birth weight, infant growth and insulin resistance. Eur J Endocrinol 2004;151:S131-9.

13 Monteiro PO, Victora CG. Rapid growth in infancy and childhood and obesity in later life-a systematic review. Obes Rev 2005;6:143-54

14 Rogers I. The influence of birthweight and intrauterine environment on adiposity and fat distribution in later life. Int J Obes Relat Metab Disord 2003:27:755-77.

15 Freud S. Sexuality and the psychology of love; the future of an illusion; three easays on the theory of sexuality; beyond the peasure principle; civilization and its discontents. Ventura, CA: Pacific, 1962

16 Victora CG, Araújo CLP, Menezes AMB, Hallal PC, Vieira MF, Neutzling MB, et al. Methodological aspects of the 1993 Pelotas (Brazil) birth cohort study. Rev Saude Publica 2006;40:39-46.

17 World Health Organization Expert Committee. Physical status, the use and interpretation of anthropometry. Geneva: WHO, 1995.

18 Achenbach TM. Manual for the child behavior checklist/4-18 and 1991 profile. Burlington, VT: University of Vermont, Department of Psychiatry, 1991.

19 Biddle S, Cavill N, Sallis J. Young and active? Young people and health-enhancing physical activity-evidence and implications. London: Health Education Authority, 1998.

20 Barros AJ, Hirakata VN. Alternatives for logistic regression in cross-sectional studies: an empirical comparison of models that directly estimate the prevalence ratio. $B M C$ Med Res Methodol 2003;3:21.

21 Victora CG, Huttly SR, Fuchs SC, Olinto MT. The role of conceptual frameworks in epidemiological analysis: a hierarchical approach. Int J Epidemiol 1997;26:224-7.

22 Korner AF, Zeanah CH, Linden J, Berkowitz RI, Kraemer HC, Agras WS. The relation between neonatal and later activity and temperament. Child Dev 1985;56:38-42.

23 Saudino KJ, Eaton WO. Continuity and change in objectively assessed temperament-a longitudinal twin study of activity level. Br J Dev Psychol 1995;13:81-95.

24 Janz KF, Dawson JD, Mahoney LT. Tracking physical fitness and physical activity from childhood to adolescence: the muscatine study. Med Sci Sports Exerc 2000;32:1250-7.

25 Malina RM. Tracking of physical activity and physical fitness across the lifespan. Res $Q$ Exerc Sport 1996;67:S48-57.

26 McMurray RG, Harrell JS, Bangdiwala SI, Hu J. Tracking of physical activity and aerobic power from childhood through adolescence. Med Sci Sports Exerc 2003;35:1914-22.
27 Alfano CM, Klesges RC, Murray DM, Beech BM, McClanahan BS. History of sport participation in relation to obesity and related health behaviors in women. Prev Med 2002;34:82-9

28 Beunen GP, Lefevre J, Philippaerts RM, Delvaux K, Thomis M, Claessens AL, et al Adolescent correlates of adult physical activity: a 26-year follow-up. Med Sci Sports Exerc 2004;36:1930-6.

29 Tammelin T, Nayha S, Hills AP, Jarvelin MR. Adolescent participation in sports and adult physical activity. Am J Prev Med 2003;24:22-8.

30 Morabia A, Costanza MC. The obesity epidemic as harbinger of a metabolic disorder epidemic: trends in overweight, hypercholesterolemia, and diabetes treatment in Geneva, Switzerland, 1993-2003. Am J Public Health 2005;95:632-5.

31 Strauss RS, Pollack HA. Epidemic increase in childhood overweight, 1986-1998. JAMA 2001;286:2845-8.

32 Mendez MA, Monteiro CA, Popkin BM. Overweight exceeds underweight among women in most developing countries. Am J Clin Nutr 2005;81:714-21.

33 Hallal PC, Victora CG, Wells JC, Lima RC. Physical inactivity: prevalence and associated variables in Brazilian adults. Med Sci Sports Exerc 2003;35:1894-900.

34 Harpham T, Huttly S, Wilson I, De Wet T. Linking public issues with private troubles: panel studies in developing countries. J Int Dev 2003;15:353-63.

35 Da Silva RC, Malina RM. Level of physical activity in adolescents from Niteroi, Rio de Janeiro, Brazil. Cad Saude Publica 2000;16:1091-7.

36 Oehlschlaeger MH, Pinheiro RT, Horta B, Gelatti C, San'Tana P. [Prevalence of sedentarism and its associated factors among urban adolescents]. Rev Saude Publica 2004:38:157-63.

37 Parks SE, Housemann RA, Brownson RC. Differential correlates of physical activity in urban and rural adults of various socioeconomic backgrounds in the United States.J Epidemiol Community Health 2003;57:29-35.

38 Pomerleau J, McKee M, Robertson A, Vaasc S, Kadziauskiene K, Abaravicius A, et al Physical inactivity in the Baltic countries. Prev Med 2000;31:665-72.

39 Dias-da-Costa JS, Hallal PC, Wells JC, Daltoe T, Fuchs SC, Menezes AM, et al. Epidemiology of leisure-time physical activity: a population-based study in southern Brazil. Cad Saude Publica 2005;21:275-82.

40 Maccoby EE, Doering CH, Jacklin CN, Kraemer H. Concentrations of sex hormones in umbilical blood: their relation to sex and birth order of infants. Child Dev 1979:50:632 42.

41 Marcus J, Maccoby EE, Jacklin CN, Doering CH. Individual differences in mood in early childhood: their relation to gender and neonatal sex steroids. Dev Psychobiol 1985;18:327-40

42 Eaton WO, Chipperfield JG, Singbeil CE. Birth order and activity level in children. Dev Psychobiol 1989;25:668-72.

43 Wells JCK, Davies PSW. Relationships between behaviour and energy expenditure in 12-week-old infants. Am J Hum Biol 1996;8:465-72.

44 Mitchell BD, Rainwater DL, Hsueh WC, Kennedy AJ, Stern MP, Maccluer JW. Familial aggregation of nutrient intake and physical activity: results from the San Antonio family heart study. Ann Epidemiol 2003;13:128-35.

45 Simonen RL, Perusse L, Rankinen T, Rice T, Rao DC, Bouchard C. Familial aggregation of physical activity levels in the Quebec family study. Med Sci Sports Exerc 2002;34:1137-42.

46 Barros FC, Victora CG, Barros AJ, Santos IS, Albernaz E, Matijasevich A, et al. The challenge of reducing neonatal mortality in middle-income countries: findings from three Brazilian birth cohorts in 1982, 1993, and 2004. Lancet 2005;365:847-54.

47 Kemper HC, Twisk JW, Koppes LL, van Mechelen W, Post GB. A 15-year physical activity pattern is positively related to aerobic fitness in young males and females (13-27 years). Eur J Appl Physiol 2001;84:395-402.

48 Kraut A, Melamed S, Gofer D, Froom P. Effect of school age sports on leisure time physical activity in adults: the CORDIS study. Med Sci Sports Exerc 2003;35:2038-42. (Accepted 15 February 2006)

doi 10.1136/bmj.38776.434560.7C

Postgraduate Program in Epidemiology, Federal University of Pelotas, Duque de Caxias 250 3* piso 96030-002 Pelotas-RS, Brazil

Pedro C Hallal associate professor

Felipe F Reichert PhD student

Cesar G Victora professor

MRC Childhood Nutrition Centre, Institute of Child Health, London

Jonathan C K Wells reader

Postgraduate Program in Epidemiology, Federal University of Pelotas; Institute of Psychology, Federal University of Rio Grande do Sul, Brazil

Luciana Anselmi PhD student

Correspondence to: P C Hallal prchallal@terra.com.br 